\title{
Expression of p97/Valosin Containing Protein in Human Sperm and Its Correlation with Semen Parameters
}

\author{
Seda Ocakli \\ Ankara Yildirim Beyazit University, Medical Faculty, \\ Dept.of Histology and Embryology, 06800, Ankara, Turkey \\ Gaziosmanpasa University, Medical Faculty, \\ Dept.of Histology and Embryology, Tokat, Turkey \\ Fikret Gevrek \\ Gaziosmanpasa University, Medical Faculty, \\ Dept.of Histology and Embryology, Tokat, Turkey \\ Fikret Erdemir \\ Gaziosmanpasa University, Medical Faculty, \\ Department of Urology, Tokat, Turkey \\ Sevil Cayli (Corresponding author) \\ Ankara Yildirim Beyazit University, Medical Faculty, \\ Dept.of Histology and Embryology, 06800, Ankara, Turkey \\ Email address: sevilcayli@yahoo.com
}

\begin{abstract}
Valosin-containing protein (VCP), also called p97, is a AAA+ ATPase that has been shown to be involved in many cellular events. However, there exist no information about the involvement of p97/VCP in infertile human sperm and its expression is not correlated with semen parameters. In this study, we aimed to investigate the expressional differences of $\mathrm{p} 97 / \mathrm{VCP}$ in fertile and infertile men and its correlation with semen parameters was observed..

We investigated the expression of $\mathrm{p} 97 / \mathrm{VCP}$ in ejaculated spermatozoa with immunocytochemistry and Western blotting in semen samples from 20 men representing a broad spectrum of semen quality. We also used donor ejaculates (n:20 men), immunocytochemistry and Western blotting were performed to detect the expression and the localization of $\mathrm{p} 97 / \mathrm{VCP}$.

p97/VCP was highly expressed in human spermatozoa. p97/VCP expression in infertile men was significantly different compared to fertile men ( $\mathrm{p}<0,05)$. p97/VCP expression correlated with classical semen parameters (concentration, morphology and motility) and was significantly higher in infertile men. In conlusion, p97/VCP was expressed in human spermatozoa and the expression correlated negatively with the classical semen parameters. Therefore, p97/VCP expression seems related to quality of the spermatozoa. We suggest that higher expression of p97/VCP may lead to abnormal maturation and reduced functionality of spermatozoa.
\end{abstract}

Keywords: Human sperm, p97/Valosin containing protein (VCP), infertility, immunocytochemistry, Western blotting

Special Issue of Health Sciences

DOI: $10.7176 /$ JSTR/6-03-39

\section{p97/Valosin İçeren Protein (VCP)'nin İnsan Sperminde Ekspresyonu Ve Bu Ekspresyonun Semen Parametreleri İle Olan İlişkisi}

Özet:

p97 olarak da adlandırılan Valosin içeren protein (VCP) hücre içi bir çok olayda görevli bir ATPazdır. Fakat p97/VCP'nin infertil insan sperminde lokalizasyonu ve ekspresyonu ve bu ekspresyonun semen parametreleri ile ilişkisi hakkında bir bilgi literatürde mevcut değildir. Bu çalışmada, p97/VCP'nin fertil 
ve infertil bireylerdeki ekspresyonundaki farklılıklar ve bu ekspresyonun semen parametreleri ile olan ilişkisinin araştırılması amaçlandı.

Fertil (n:20 kontrol ejakülatı) ve infertil bireylerin (n:20 erkek hasta ejakülatı) sperm örnekleri üzerinde immunositokimyasal teknikler ve Western blot uyguland. Kontrol ve hasta spermlerine ait örneklerde semen parametreleri (konsantrasyon, motilite ve morfoloji) değerlendirildi.

Sonuçlarımız UPS proteinlerinden, p97/VCP'nin sperm baş, boyun ve kuyruk bölgesinde lokalize olduğunu göstermiştir. Fakat bu lokalizasyonun en fazla baş bölgesinde yerleşim gösterdiği ve özellikle de infertil bireylerde p97/VCP'nin fertil bireylere göre ekspresyonun daha fazla olduğu saptanmıştır. p97/VCP ekspersyonu ile semen parametreleri arasında negatif bir korelasyon bulunmuştur. $\mathrm{Bu}$ sonuçlar p97/VCP'nin erkek infertilitesi değerlendirilmesinde kullanılabilecek bir kriter olabileceğini göstermektedir.

Sonuç olarak, fertil ve infertil bireyler arasında p97/VCP'nin ekspresyonu arasında anlamlı derecede farklılıkların bulunması ve semen parametreleri ile p97/VCP arasındaki negatif ilişkinin saptanması, p97/VCP'nin sperm maturasyonu ve sperm fonksiyonu ile ilişkili bir protein olduğunu ve erkek infertilitesinin değerlendirilmesinde kullanılabilecek bir faktör olabileceğini göstermektedir.

Anahtar kelimeler: İnsan spermi, p97/Valosin içeren protein (VCP), kısırlık, immunositokimya, Western blotlama

\section{Giriş:}

İnfertilite, kontraseptif bir yöntem uygulamadan, düzenli bir cinsel yaşama rağmen bir yıl süreyle gebelik oluşmaması olarak tanımlanır. Kliniklere infertilite problemi ile başvuran çiftlerin \% 48 'inde erkeğe bağlı faktörün olması erkek fertilizasyon potansiyelinin araştırılmasını bir ön koşul olarak beraberinde getirmektedir. Erkeklerde anatomik, endokrin, immünolojik bir bozukluk veya infeksiyon infertilite nedeni olabilir. İnfertilitede erkek faktörünün kesinlik kazanabilmesi için; öykü, genel fizik muayene, semen analizi ve hormonal tetkikler sırasılla yapılmalı ve gereğinde testis biyopsisi; biyokimyasal ve fonksiyonel testlerle desteklenmelidir (Delilbaş1, 1997; Günalp, 2004; Lens, 1996).

Son yıllarda yapılan moleküler çalışmalarda erkek infertilitesinin değerlendirilmesinde belli molekül ve proteinlerin önemi ve bunların infertilite ile ilişkilendirilmesine dair çok sayıda çalışma gündeme gelmiştir (Aarabi vd, 2014; Murgia vd., 2020). Bunlardan Ubikütin proteazom sisteminde (UPS) çalışan ve çok fonksiyonlu bir protein olan p97/Valosin içeren protein (VCP)'nin erkek infertilitesiyle ilişkisine dair kısıtlı sayıda literatürde bilgi vardır (Ficarro vd., 2003; Song vd., 2016; Sutovsky vd., 2017). p97/VCP'nin, ilk olarak bizim çalışmalarımızla (Cayli vd., 2011; Cayli vd., 2012) gelişmekte olan sıçan testis ve epididimis dokularındaki ekspresyonları belirlenmiştir. Testiküler dokularda p97/VCP'nin gelişime paralel olarak ekspresyonlarının arttığı ve farklı UPS proteinleri ile ilişkide olduğu belirlenmiştir.

p97/VCP'nin, hücreiçi birçok temel fonksiyonu (Endoplazmik reticulum ilişkili protein y1kımı, hücre siklusu kontrolü, apoptoz, otofaji gibi) yerine getirdiği bilinmektedir (Dargemont vd., 2012; Meusser vd., 2005; Ogura vd., 2001). p97/VCP'nin bir çok hastalık patogenezindeki rolleri de büyük ölçüde bilinmektedir (Pickard vd., 2001). Fakat p97/VCP'nin erkek üreme hücresi olan spermlerde bugüne kadar varlığı ve fonksiyonu hakkında çalışma yok denecek kadar azdır. Bu nedenle bu çalışmada öncelikle biz p97/VCP'nin fertil ve infertil bireylerin spermlerinde immunohistokimyasal ve Western blot yöntemleriyle lokalizasyonunu ve ekspresyonunu belirlemeyi amaçladık, ikincil olarak da p97/VCP'nin bu bireylerdeki semen parametreleri ile olan ilişkisini incelemeyi amaçladık.

\section{Yöntem:}

\section{1.Örneklerin Temini ve Gruplandırılması}

Gaziosmanpaşa Üniversitesi Etik Kurulu kararı doğrultusunda planlanan bu çalışmada, GOP Üniversitesi Tıp Fakultesi Üroloji polikliniğine infertilite problemi ile müracaat ederek spermiyogram tetkiki yaptırması tavsiye edilen hastaların semen örnekleri, olguların olurları alındıktan sonra bu çalışmada kullanılmıştır. Semen örnekleri spermiyogram özellikleri yönünden değerlendirilip sonuçları rapor edildikten sonra çalışma için ayrılmıştır.

Hastalar ile yapılan ilk görüşmede örnek vermeğe gelecekleri gün 3-5 günlük bir cinsel perhiz süresine uyarak gelmeleri tavsiye edilmiştir. Önerilen cinsel perhiz süresine uyulduğunda, dikkatli bir şekilde yapılan semen analizi testislerin spermatogenetik ve steroidogenetik aktivitesiyle aksesuvar bezlerin çalışması hakkında sağlıklı bilgi sahibi olunmasını sağlayacaktır. Hastaların steril şartlarda, steril kutular kullanarak bu amaçla düzenlenmiş sperm verme odasını kullanmaları sağlanmıştır. Hastalar, mastürbasyonla örnek vermeleri gerektiği konusunda bilgilendirilmiş, kullandıkları kutuların üzerine isimleri etiketle yapıştırılmıştır. Örnek verme esnasında nelere dikkat etmeleri gerektiği önceden 
hazırlanmış bir bildiri ile kendilerine açıklanmıştır. Örnek toplanması esnasında krem ya da kayganlaştırıcı bir madde kullanmaması, örnek toplanan kutuya su ya da başka bir madde kaçırmaması söylenmiştir. Semen toplanan kutuyla ilgili olarak daha önceden yapılan kimyasal ve biyolojik testlerle toksik olmadığı ispatlanmış kutular satın alınmıştır. Hastanın örneğini aldıktan sonra kendi eli ile laboratuvardaki ilgili görevliye teslim etmeleri gerektiği izah edilmiştir. Semen örnekleri spermiyogram özellikleri yönünden değerlendirilip sonuçları rapor edildikten sonra çalışma için ayrılmıştır. Örneklerin ayırımı yapılırken lökosit içeren, viskoz olan ve anormal bir görüntüye sahip (örneğin kanlı) örnekler çalışmaya alınmamış, perhiz süresine uygun olarak (ortalama 3-5 gün) toplanmış örnekler seçilmeye dikkat edilmiştir. Örnekler spermiyogram özelliklerine göre; hacim, konsantrasyon, motilite ve morfoloji yönünden değerlendirilmiş ve hastaların ayrıntılı anemnezleri alınmıştır. Kriptorşidizm, geçirilmiş genital infeksiyon hikayesi, genital travma, geçirilmiş operasyonlar, alışkanlıklar (sigara, alkol, uyuşturucu kullanımı), radyasyon tedavisi, kemoterapi gibi maruz kalınan gonodotoksinler sorgulanmış ve bu hastalar fertil gruba dahil edilmemiştir. Hastaların testis sayıları, lokalizasyonu ve volümü kaydedildi. Varikosel varlığı fizik muayene ile belirlendi. Ayrıca epididim ve vas deferensin skrotal kısımlarının palpasyonu yapıldı. Vaz deferens obstrüksiyonu ya da agenezisi şüphesi olan hastalar ile daha önce fertilizasyon amacı ile vazektomi yapılan hastalar çalışmaya alınmadı. Infertil grubun yanında, fertil kontrol grubu daha önce çocuğu olan ve yukarıda belirtilen kriterlere sahip olmayan bireylerden seçildi. Dünya Sağlık Örgütü'nün 2010 verilerine göre konsantrasyon, motilite ve morfoloji için normal olarak kabul edilen değerler: Hacim $\geq 1,5 \mathrm{ml}$, Konsantrasyon $\geq 15 \times 106 / \mathrm{ml}$, Motilite $>\% 40$, Morfoloji $\geq$ $\% 4$ (Kruger). Fertil $(\mathrm{n}=20)$ ve infertil $(\mathrm{n}=20)$ bireylerden alınan semen örnekleri üzerinde immunohistokimya için hazırlıklar aşağıda belirtildiği şekilde hazırlandı.

\subsection{Sperm Yıkama}

Ejakülat $37^{\circ} \mathrm{C}$ 'de likefiye olduktan sonra mikroskopik olarak incelenir ve $2500 \mathrm{rpm}$ 'de 10 dakika santrifüj edilir. Santrifüj sonrası seminal sıvı içeriği üstten ayrı bir tüpe alınır. Altta kalan sperm pellleti üzerine $500 \mu \mathrm{l}-2 \mathrm{ml}$ arası (tüpte kalan sperm pelletinin konsantrasyonuna yani pelletin büyüklüğüne göre) yıkama medyumu (Yıkama medyumu olarak hücre kültür işlemlerinde kullanılan bikarbonat, Hepes içermeyen tampon ve İnsan Serum Albümin içeren medyumlar tercih edilmektedir) eklenerek resuspanse edilir. Yıama medyumu $37^{\circ} \mathrm{C}$ 'de $\% 5^{\prime}$ lık CO2'e ayarlanmış inkübatörde bir saat bekletilmiș olması gerekir. Resüspansiyon sonrası sperm morfoloji değerlendirmesi için lam üzerine 5-10 $\mu$ lik örnek çekilerek yayma yapılır. Polilizinle kaplı lamlara ise yine 5-10 $\mu$ l aynı örnekten yayma yapılarak, preparatlar kuruduktan sonra $4 \%$ lük formaldehit ile fikse edilir. Fikse edilen slaytlar immusitokimyasal işlemlere başlayana kadar $4^{\circ} \mathrm{C}$ 'de saklandı.

\section{3.İmmunositokimya}

Fertil ve infertil bireylerden hazırlanan fikse edilmiş slaytlar pappen yardımıyla çizildikten sonra, oda 1sısında kesitler spesifik olmayan reaksiyonu engellemek için 1 saat $5 \%$ lik bovin serum albümin ile inkübe edildi. 1 saatlik inkübasyon sonrası, PBS ile oda sıcaklığında yıkamadan sonra sırayla biotinlenmiş sekonder antikorlar (ScyTek Laboratories, USA) ve peroksidaz-işaretli streptavidin (ScyTek Laboratories, Utah, USA) ile toplam 60 dakika inkübe edildi. Sekonder antikordaki peroksidaz aktivitesi, DAB (Sigma, USA) kromojeni ile inkübasyon sonucu görünür hale getirilip, Mayer'in hematoksileni (ScyTek Laboratories, Utah, USA) ile zit boyama yapıldı. Sonrasında, slaytlar kapatma solusyonu (Fisher Chemicals, Springfield, NJ, USA) ile kapatıldı. Kontroller için, kesitler primer antikorla benzer konsantrasyonda normal tavşan serumuyla inkübe edildi. Boyanan kesitler Leica mikroskop (Leica DM2500, Nussloch, Almanya) altında fotoğraflandırıldı. Sekonder antikorun horseradish peroxidase (HRP) ya da alkaline fosfotaz (AP) ile konjuge olma durumuna göre, AEC nin yanında, DAB veya Fast red gibi kromojenler de kullanılarak immunopositif bölgeler görünür hale getirildi.

\subsection{Western blot analizi}

Sperm örnekleri PBS ile yıkandıktan sonra, elde edilen pellet RIPA solusyonu (lizis solüsyonu) içerisinde 3 kez 5 saniye sonikasyona tabii tutuldu ve sonrasında 14000 RPMI'da, $+4{ }^{\circ} \mathrm{C}$ 'de santrifüj edildi. Santrifüj sonrası elde edilen süpernatan yükleme solüsyonu (10X laemli buffer) ile karıştırıldı ve $96^{\circ} \mathrm{C}^{\prime} \mathrm{de}$ 10 dakika kaynatılarak proteinlerin denatüre olması sağlandı. \%4 -12'lik Bis- Tris Jel (1.0 mmX10 well)'e kaynatılan örnekler yüklendi ve 120 Volt, 300 miliamper ve 250 Watt ayarında 1 saat 40 dakika yürütüldü. Yürütme bittikten sonra, semidry blotlama metodu ile jeldeki proteinlerin, nitrosellüloz membranlara aktarımı 150 mAmperde 1 saat süre ile gerçekleştirildi. Membrana aktarılan proteinler Ponceu-S boyası ile boyandı ve PBS-Tween ile sonrasında $3 \mathrm{kez} 5$ 'er dakika yıkandı. Sonrasında membrane \%5'lik süttozu ile blokland. Sirasıyla primer antikor (anti mouse p97/VCP antikoru, Abcam, 
ab11433) ile gece boyu $4^{0} \mathrm{C}^{\prime}$ de ve ertesi gün anti mouse HRP işaretli sekonder antikor ile inkübe edildi. Sekonder antikor ile inkübasyonun ardından üç kez PBS Tween ile yıkanan membran ECL Detection Ajanı ile 2-5 dakika inkübe edildi ve UVP Görüntüleme cihazı kullanılarak membran üzerindeki proteinler görüntülendi. Membran üzerindeki bantların densitesi Image J programı kullanılarak değerlendirildi.

\subsection{Semiquantitative HSCORE analizi}

Herbir kesit için ışık mikroskobu altında 40X büyütmede birbirinden habersiz iki araştırmacı tarafindan rastgele beş alan seçildi ve bu alanlar içinde hücrelerin boyanma yoğunluğuna göre [0 (boyanma yok), +1 (zayıf, fakat tespit edilebilir boyanma), +2 ( orta şiddetli boyanma) ve +3 (yoğun boyanma) hücre sayımı yapıldı (Cayli S, 2011). Hesaplama için HSCORE formulü kullanıldı [ $\Sigma$ Pi(i+ 1): i boyanma yoğunluğu skorunu, Pi boyanan hücrelerin yüzdesini gösterir]. İki gözlemcinin hesapladığı skorların ortalaması alındı ve HSCORE değerleri grafikle gösterildi.

İstatiksel değerlendirmeler SigmaStat versiyon 3.5 (Jandel Scientific Corp., San Rafael, CA) kullanılarak ve anlamlılık $\mathrm{p}<0.05$ olarak değerlendirilmiştir. Fertil ve infertil hasta gruplarında ortaya çıkabilecek muhtemel farklılıklar karşılaştırmalı testler (ANOVA, t-test) ve korelasyon regresyon analizleri (Pearson, Spearman) ile değerlendirildi.

\section{Sonuçlar:}

\subsection{Semen parametreleri}

Çalışmamızda kullandığımız fertile ve infertil bireyler için 20'şer hastaya ait semen parametreleri (konsantrasyon, motilite, morfoloji) ve hasta yaşı değerleri tablo 1'de gösterilmiştir.

Tablo 1: Fertil ve infertil hastalarda semen parametreleri

$\begin{array}{lcc} & \text { FERTIL (n:20) } & \text { INFERTIL (n:20) } \\ \text { Sperm konsantrasyonu }\left(\mathbf{x 1 0}^{\mathbf{6}}\right) & 132,6 \pm 5,6 & 32,6 \pm 5,8 \\ \text { Motilite }(\%) & 68,7 \pm 6,8 & 33,7 \pm 8,3 \\ \text { İleri motil sperm (\%) } & 62,2 \pm 3,5 & 25,5 \pm 5,4 \\ \text { Normal morfoloji }(\%) & 91 \pm 5,4 & 58 \pm 2,6 \\ \text { Yaş } & 29,2 \pm 6,5 & 28,8 \pm 6,4 \\ \text { Ejakülat volümü } & 3,27 \pm 3,6 & 2,8 \pm 4,2\end{array}$

\subsection{Fertil ve infertil bireylerde p97/VCP ekspresyonun belirlenmesi}

İmmunositokimyasal işlemler sonrası fertil ve infertil bireylerden elde edilen sperm yaymalarında p97/VCP proteininin sperm hücrelerinde lokalizasyonu belirlendi (Şekil 1a). Yapılan immusitokimyasal işaretlemeler sonrası, p97/VCP'nin özellikle baş, boyun ve kuyruk bölgelerinde değişik yüzdelerde lokalize olduğu belirlendi (Şekil 1a, oklar). Fertil ve infertil bireylerdeki p97/VCP pozitif hücrelerin yüzdeleri karşılaştırıldığında infertil bireylerde anlamlı derecede p97/VCP pozitif hücrelerin yüzdelerinin artmış olduğu saptandı (Şekil 2). 


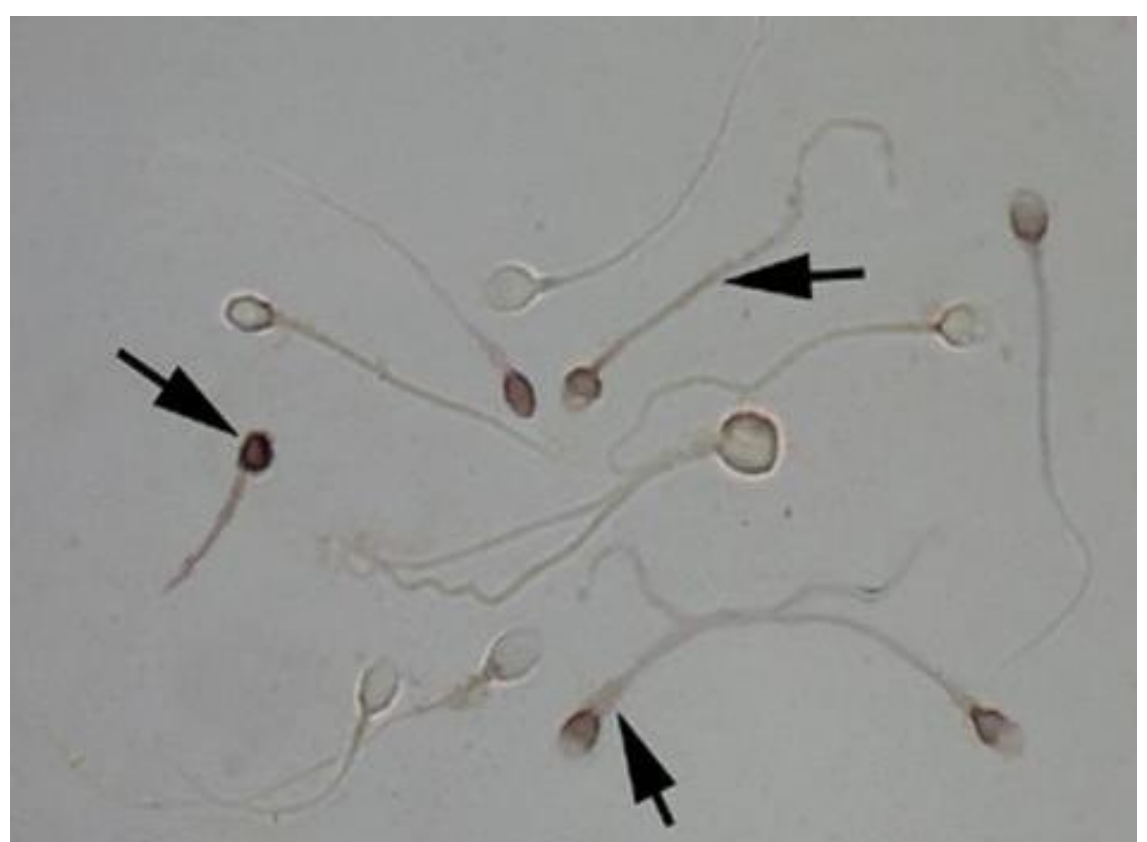

Şekil 1: İnfertil bireye ait semen yaymasında p97/VCP immunopozitif işaretli spermler. p97/VCP'nin baş, boyun ve kuyruk bölgelerindeki immunolokalizasyonu izlenmektedir.

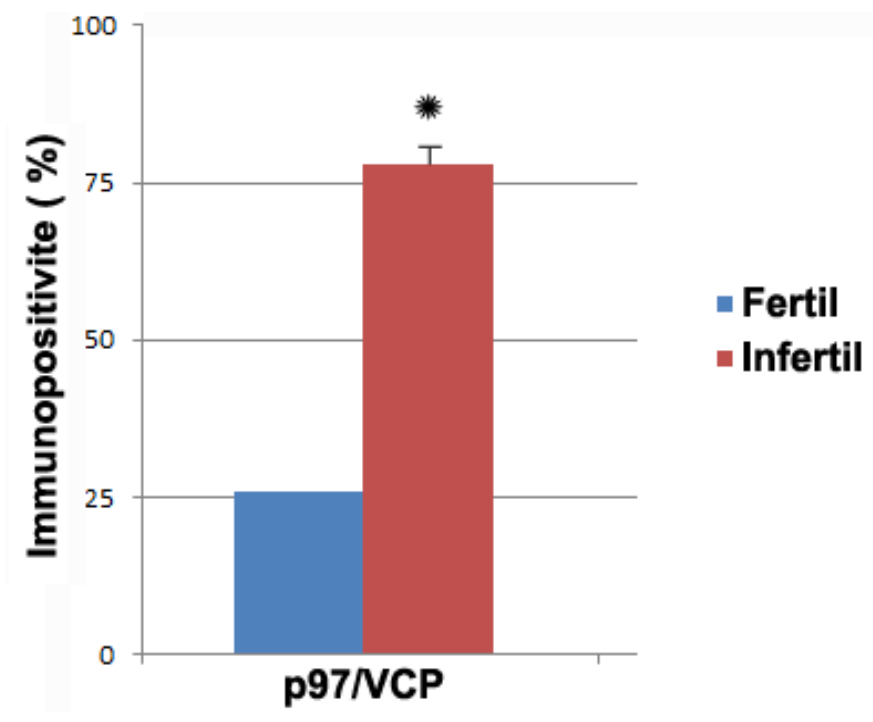

Şekil 2. Fertil ve infertil bireylerde p97/VCP immunpozitivitesinin karşılaştırılması. Fertil bireylerde p97/VCP immuno ekspresyonunun infertil bireylere göre anlamlı derecede az olduğu görüldü. (yıldız:p $<0,001$ ).

\section{3. p97/VCP ekspresyonunun semen parametreleri ile olan ilişsisi}

p97/VCP immunopozitif sperm yüzdelerinin, o ejakülattaki sperm konsantrasyonu ile ilişkisi olup olmadığını anlamak amacıyla Pearson korelasyonu ile pozitif ve ya negatif yönde bir ilişki olup olmadığına bakıldı (Şekil 3). 20 hasta ile yapılan korelasyon eğrisinde de görüldüğü üzere, p97/VCP immunoreaktivitesinin sperm konsantrasyonu ile ters orantılı fakat anlamlı derecede ilişkili olduğu bulunmuştur. 


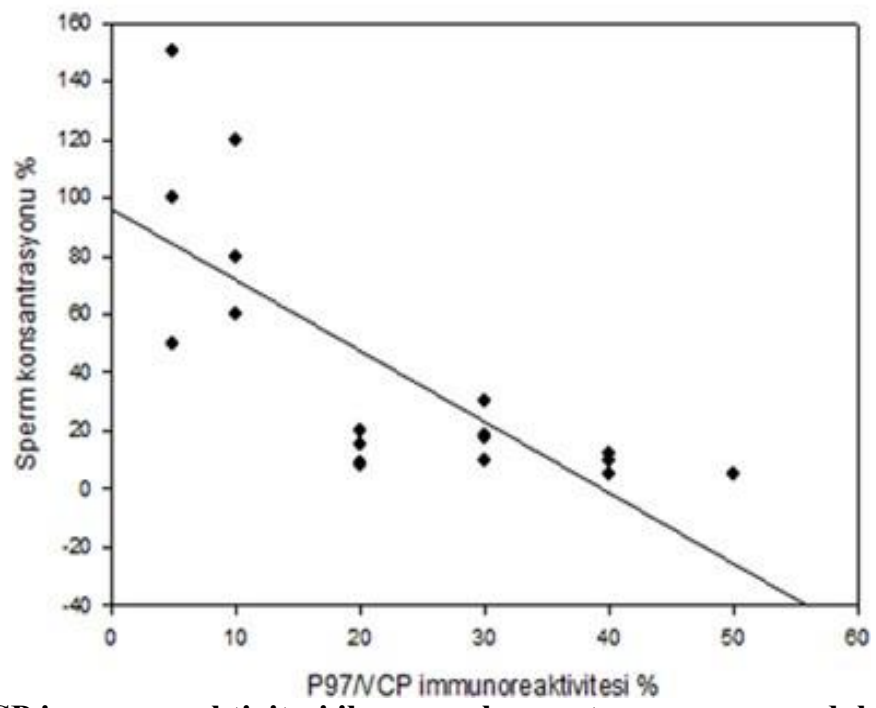

Şekil 3. p97/VCP immunoreaktivitesi ile sperm konsantrasyonu arasındaki negatif ilişkiyi gösteren 20 hastadaki korelasyon.

Yani, sperm konsantrasyonu yüksek olan hastalarda, p97/VCP immunoreaktivitesinin düşük olduğu saptanmıştır.

\section{4. p97/VCP ekspresyonunun sperm motilitesi ile olan ilişkisi}

p97/VCP immunopozitif sperm yüzdelerinin, o ejakülattaki sperm motilitesi ile ilişkisi olup olmadığını anlamak amacıyla Pearson korelasyonu ile pozitif ve ya negatif yönde bir ilişki olup olmadığına bakıldı (Şekil 4). 20 hasta ile yapılan korelasyon eğrisinde de görüldüğü üzere, p97/VCP immunoreaktivitesinin sperm motilitesi ile ters orantılı fakat anlamlı derecede ilişkili olduğu bulunmuştur. Yani, sperm motilitesi yüksek olan hastalarda, p97/VCP immunoreaktivitesinin düşük olduğu saptanmıştır (Şekil 4).
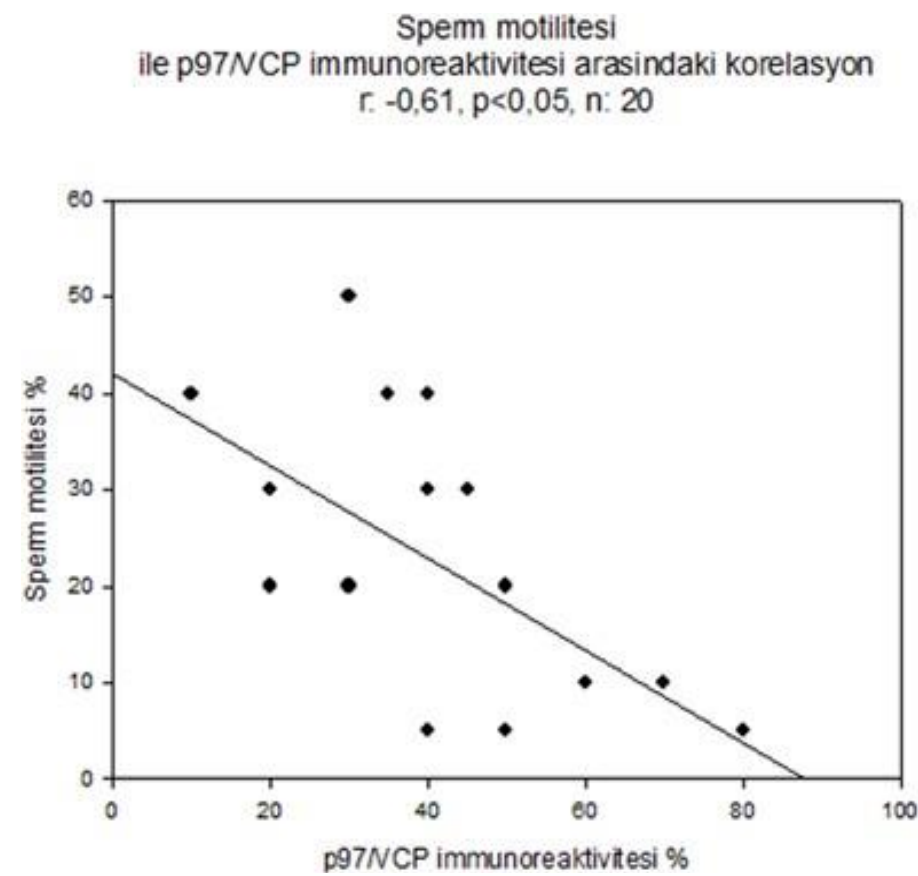

Şekil 4. p97/VCP immunoreaktivitesi ile sperm motilitesi arasındaki negative ilişkiyi gösteren 20 hastadaki korelasyon. 


\section{5. p97/VCP ekspresyonunun sperm morfolojisi ile olan ilişkisi}

p97/VCP immunopositif sperm yüzdelerinin, o ejakülattaki sperm morfolojisi ile ilişkisi olup olmadığını anlamak amacıyla Pearson korelasyonu ile pozitif ve ya negatif yönde bir ilişki olup olmadığına bakıldı (Şekil 5). 20 hasta ile yapılan korelasyon eğrisinde de görüldüğü üzere, p97/VCP immunoreaktivitesinin sperm morfolojisi ile ters orantılı fakat anlamlı derecede ilişkili olduğu bulunmuştur. Yani, sperm morfolojisi iyi olan hastalarda, p97/VCP immunoreaktivitesinin düşük olduğu saptanmıştır (Şekil 5).

\section{Sperm morfolojisi \\ ile p97/NCP immunoreaktivitesi arasindaki korelasyon \\ r: $-0,81, p<0,05, n: 20$}

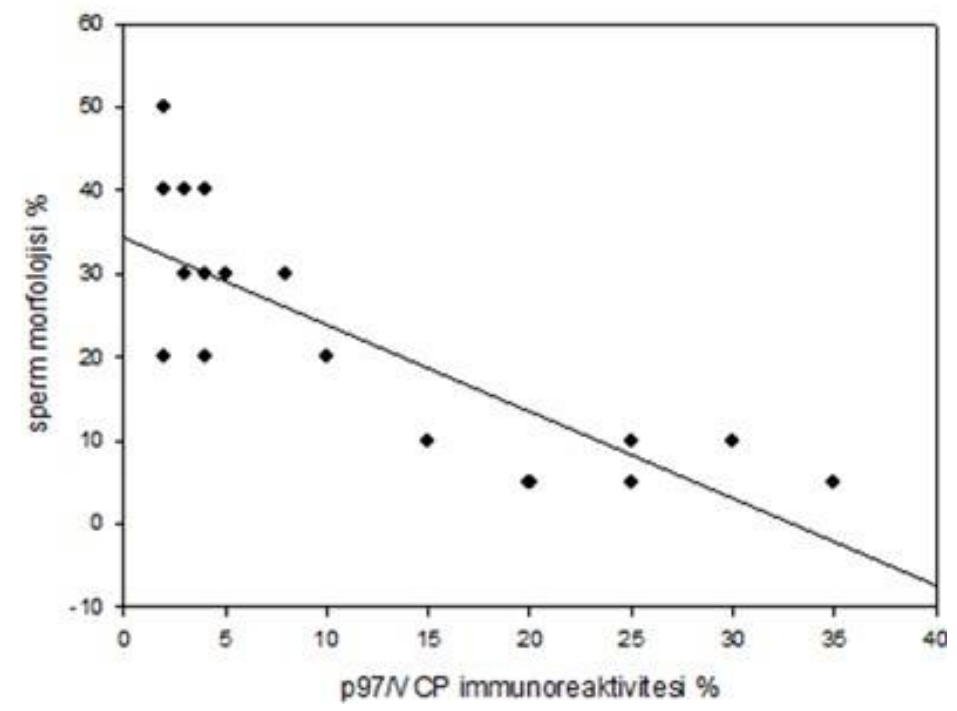

Şekil 5. p97/VCP immunoreaktivitesi ile sperm morfolojisi arasındaki negatif ilişkiyi gösteren 20 hastadaki korelasyon.

3.6. p97/VCP ekspresyonunun fertile ve infertil bireylerde Western blot ile değerlendirilmesi İmmunositokimyasal olarak fertil ve infertil insan sperminde belirlenen p97/VCP'nin ekspresyonu Western blot yöntemiyle aynı hastalarda değerlendirildi. Western blot çalışmaları sonucunda elde edilen band yoğunlukları Image J program ile değerlendirldikten sonra, p97/VCP ekspresyonunda fertil ve infertil hastalar arasında anlamlı ölçüde farklı olduğu saptandı (Şekil 6).

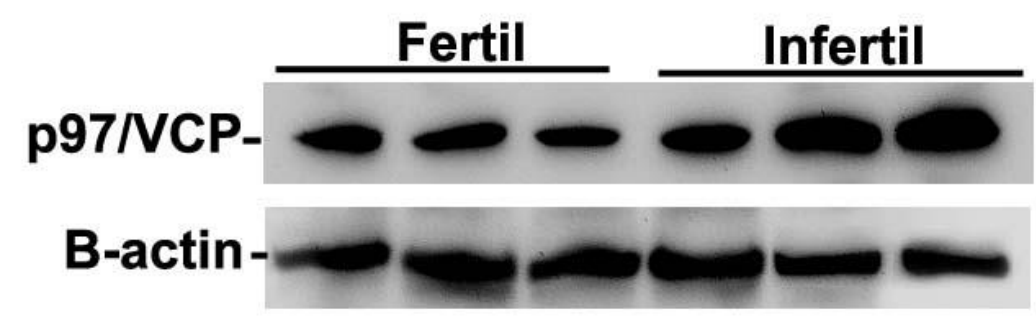

Şekil 6. P97/VCP ekspresyonunun fertil ve infertil bireylerde örnek üç hastadaki Western blot ile gösterimi. İnfertil bireylerde p97/VCP ekspresyonun Beta actin ile orantılandığında arttığı izlenmektedir

\section{Tartışma}

$\mathrm{Bu}$ çalışmada, fertil ve infertil bireylerde UPS proteinlerinden p97/VCP'nin sperm hücrelerinde lokalizasyonu ve p97/VCP ekspresyonunun semen parametreleri ile ilişkisi incelemektedir. p97/VCP'nin insan sperminde ilk defa ekspresyonunun gösterilmesi ve bu ekspresyonun semen parametreleri ile ilişkisinin olup olmadığının incelenmesi nedeniyle orijinal bulgular içermektedir. Bu projede kullanılan temel metodlar immunositokimya ve Western blottur.

Sonuçlarımız UPS proteinlerinden, p97/VCP'nin sperm baş, boyun ve kuyruk bölgesinde lokalize olduğunu göstermiştir. Fakat bu lokalizasyonun en fazla baş bölgesinde yerleşim gösterdiği ve özellikle de infertil bireylerde p97/VCP'nin fertil bireylere göre ekspresyonun daha fazla olduğu saptanmıştır. Bu 
sonuçlar p97/VCP'nin erkek infertilitesi değerlendirilmesinde kullanılabilecek bir kriter olabileceğini göstermektedir.

Bugüne kadar p97/VCP'nin sperm hücresindeki fonksiyonları ile ilgili yapılan çalışmalar çok azdır (Ficarro vd., 2003; Kondoh vd., 2008; Hozumi vd., 2008;). Bu çalışmalarda da direk insan spermindeki fonksiyonu tam olarak belirlenememiştir. Yalnız, Ficarro vd., 2003 kapasite olmuş insan sperminde yaptıkları kütle spektrometrisi çalışmalarında p97/VCP'nin sperm kapasitasyonu sırasında fosforile olduğunu göstermişlerdir. Yine bu çalışmada, kapasite olmuş ve olmamış sperm hücrelerinde p97/VCP'nin lokalizasyonu belirlenmiştir. Örneğin kapasite olmamış spermlerde, p97/VCP spermin boyun bölgesinde lokalize iken, kapasitasyon sonrası bu lokalizasyonun değiştiği ve sperm başında görülmeye başlandığı saptanmıştır (Ficarro vd., 2003). Kapasitasyon memeli sperminin fertilizasyonu gerçekleştirebilmesi için gereklidir. Bu olay sırasında birçok proteinin tirozin kuyrukları fosforile olur ve spermin hareketinin arttığı gözlenmiştir. Kapasitasyon akrozomal reaksiyon içinde gereklidir. Bu derece fertilizasyon için önemli bir olayda p97/VCP'nin de fosforile olduğunu bilmek, bu proteinin kapasitasyon için ne kadar önemli bir protein olduğunu göstermektedir. Biz de çalışmamızda sperm hücrelerinde p97/VCP'nin özellikle de baş ve kuyruk bölgelerinde var olduğunun gösterilmesiyle Ficarro ve arkadaşlarını destelemiş olduk.

Kondoh ve arkadaşlarının yaptığı bir çalışmada, p97/VCP'nin bir deniz hayvanı spermlerinde değil de, spermi ovosite çeken kemoatraktan bir madde olan sperm aktive edici faktör (SAAF)'e bağlandığ belirlenmiştir (Kondoh vd.,2008). p97/VCP'nin başlangıçta germinal vesikül aşamasındaki ovositte lokalize olduğu ve oosit olgunlaşması için gerekli olduğu bulunmuştur. Yine aynı çalışmada, p97/VCP'nin yumurtadan salınan SAAF denilen faktörün çalışmasını düzenlediği ortaya çıkarılmıştır. p97/VCP'nin siliar ve flagellar hareket için gerekli olduğu başka bir çalışmada gösterilmiştir (Hozümi vd., 2008). Yalnız bu çalışma yine insan sperminde değil, deniz hayvanı sperminde siliar hareket için gerekli olan proteinlerin araştırılması sırasında p97/VCP'nin gerekliliğini ortaya koymuştur. Bizim çalışmalarımızla uyumlu olarak bu çalışmada da sperm kuyruğunda p97/VCP'nin görülmesi, p97/VCP'nin sperm hareketliliği ile ilişkisi olabileceğini göstermektedir.

Özetle, p97/VCP'nin insan sperm hücrelerindeki varlığı ve infertil bireylerde p97/VCP'nin anlamlı derecede fazla olmas1, p97/VCP'nin sperm maturasyonu ve infertiliteyi etkileyen önemli bir protein olduğunu göstermektedir. p97/VCP'nin fertil ve infertil bireylerde farklı ekspresyon göstermesi nedeniyle bu çalışmanın daha detaylı moleküler çalışmalarla desteklenerek klinikte prognozda ve ya tedavide bir belirteç olarak kullanılması önerilmektedir.

\section{Referanslar:}

Aarabi M, Balakier H, Bashar S, Moskovtsev SI, Sutovsky P, Librach CL, Oko R. Sperm content of postacrosomal WW binding protein is related to fertilization outcomes in patients undergoing assisted reproductive technology. Fertil Steril. 2014 Aug;102(2):440-7.

Cayli,S., Ocakli, S., Erdemir, F, Tas, U., Aslan, H., Yener, T., Karaca, Z., 2011. Developmental expression of p97/VCP (Valosin containing protein) and Jab1/CSN5 in the rat testis and epididymis. Reproductive Biology and Endocrinology 9, 117.

Cayli, S., Erdemir, F., Ocaklı, S., Ungor, B., Kesici, H., Yener, T., Aslan, H., 2012. Interaction between Smad1 and p97/VCP in rat testis and epididymis during the postnatal development. Reproductive Sciences. 19(2), 190-201.

Dai, R.M., Li, C.C., 2001. Valosin-containing protein is a multi-ubiquitin chain-targeting factor required in ubiquitin-proteasome degradation. Nat Cell Biol 3, 740-744. Delilbaş1, L., 1997. Tüp Bebek-Yardımcı Üreme Tekniklerinde Laboratuar Yöntemleri.Bayındır Sağlık, Eğitim ve Araştırma Vakfi, Ankara.

Dargemont C, Ossareh-Nazari B. Cdc48/p97, a key actor in the interplay between autophagy and ubiquitin/proteasome catabolic pathways. Biochim Biophys Acta. 2012 Jan;1823(1):138-44.

Ficarro,S., Chertihin, A., Westbrook, A., White, F., Jayes, F., Kalab, F., Marto, JA., Shabanowitz, J., Herr,JC., Hunt, D.F and Visconti, PE., 2003; 278 (13): 11579-11589. 
Günalp, S., 2004. Kadın Doğum Hekiminin Erkek Faktörünün Araştırılması ve Değerlendirilmesindeki Rolü Ne Olmalıdır? Türk Jinekoloji ve Obstetrik Derneği Uzmanlık Sonrası Eğitim Dergisi, 729:129-140.

Hozumi, A., Padma, P., Toda, T.,Ide, H., Inaba, K., 2008. Molecular Characterization of Axonemal Proteins and Signaling Molecules Responsible for Chemoattractant-Induced Sperm Activation in Ciona intestinalis. Cell Motility and the Cytoskeleton 65, 249-267.

Kondoh, E., Konno, A., Inaba, K., Oishi,T., Murata, M.,Yoshida, M., 2008. Valosin-containing protein/p97 interacts with sperm-activating and sperm-attracting factor (SAAF) in the ascidian egg and modulates sperm-attracting activity Develop. Growth Differ. 50, 665-673.

Lens, JW., 1996. The Spermatozoon. Bras M, Lens JW, Piederiet MH, IVF lab-Laboratory aspects of in vitro fertilization, Organon pres.

Pickart CM. Ubiquitin enters the new millennium. Mol Cell. 2001 Sep;8(3):499-504

Ozsoy AZ, Cayli S, Sahin C, Ocakli S, Sanci TO, Ilhan DB. Altered expression of p97/Valosin containing protein and impaired autophagy in preeclamptic human placenta. Placenta. 2018 Jul;67:45-53. doi: 10.1016/j.placenta.2018.05.013

Ogura, T., Wilkinson, A.J., 2001. AAA+ superfamily ATPases: common structure--diverse function. Genes Cells 6, 575-597.

Meusser, B., Hirsch, C., Jarosch, E., Sommer, T., 2005. ERAD: the long road to destruction. Nat Cell Biol 7, 766-772.

Murgia F, Corda V, Serrenti M, Usai V, Santoru ML, Hurt KJ, Passaretti M, Monni MC, Atzori L, Monni G. Seminal Fluid Metabolomic Markers of Oligozoospermic Infertility in Humans. Metabolites. 2020 Feb 11;10(2). pii: E64. doi: 10.3390/metabo10020064.

Sutovsky P, Song WH. Post-fertilisation sperm mitophagy: the tale of Mitochondrial Eve and Steve. Reprod Fertil Dev. 2017 Jan;30(1):56-63. doi: 10.1071/RD17364. Review.

Song WH, Yi YJ, Sutovsky M, Meyers S, Sutovsky P. Autophagy and ubiquitin-proteasome system contribute to sperm mitophagy after mammalian fertilization. Proc Natl Acad Sci U S A. 2016 Sep 6;113(36):E5261-70. doi: 10.1073/pnas.1605844113. Epub 2016 Aug 22. 